\title{
Optimization of viral profiling approaches reveals strong links between viral and bacterial communities in a eutrophic freshwater lake
}

\author{
Dana M. Hardbower ${ }^{1,2}$, Jessica L. Dolman², Dustin R. Glasner ${ }^{2,3}$, Joseph A. Kendra ${ }^{2}$, \\ Kurt E. Williamson ${ }^{2, *}$ \\ ${ }^{1}$ Interdisciplinary Graduate Program for the Biological and Biomedical Sciences, Vanderbilt University, Nashville, \\ Tennessee 37212, USA \\ ${ }^{2}$ Department of Biology, College of William and Mary, 3035 Integrated Science Center, Williamsburg, Virginia 23185, USA \\ ${ }^{3}$ Laboratory of Retroviruses, Division of Viral Products, Center for Biologics Evaluation \& Research, \\ U.S. Food \& Drug Administration, Bethesda, Maryland 20892, USA
}

\begin{abstract}
The goals of this 18 mo field study were to examine temporal changes in viral community composition in a temperate eutrophic freshwater lake (Lake Matoaka) and to identify potential drivers of seasonal changes in microbial community composition. We show that analyses of aquatic viral community composition can be streamlined by concentrating viruses from small water samples without compromising the resolution of the community profile data. The use of small-volume viral concentrates paired with randomly amplified polymorphic DNA (RAPD) polmerase chain reaction (PCR) generated significantly richer and more complex banding patterns than the use of pulsed-field gel electrophoresis (PFGE) and the large-volume concentrates that PFGE requires. Thus, the small-volume RAPD-PCR approach was used in the subsequent analyses. Viral and bacterial communities in Lake Matoaka were highly dynamic, exhibiting strong seasonal shifts. However, repeating annual patterns were not detected among the bacterial or viral communities. Temperature was the most important factor explaining changes in viral and bacterial abundance. Viral and bacterial abundance were also significantly correlated to each other. Multivariate analysis indicated weak relationships between temperature and bacterial community composition and between temperature and viral community composition. Mantel tests revealed a strong and significant correlation between viral and bacterial community composition. Taken together with the correlation between viral and bacterial abundance, these data suggest that phages dominate the virioplankton of Lake Matoaka and indicate tightly linked phage-host dynamics.
\end{abstract}

KEY WORDS: Virioplankton - Bacterioplankton - RAPD-PCR · tRFLP - Eutrophic lake · Community dynamics

\section{INTRODUCTION}

In freshwater ecosystems, the community composition of bacterioplankton shows strong seasonal patterns, particularly in temperate lakes (Pernthaler et al. 1998, Hofle et al. 1999, Van der Gucht et al. 2001, Zwisler et al. 2003, Kent et al. 2004, Wu \& Hahn 2006). Changes in freshwater bacterial community composition may be driven by bottom-up factors, such as quality and quantity of organic matter (Crump et al. 2003), top-down factors, such as protozoan grazing or viral infection (Weinbauer \& Hofle 1998), and environmental factors, such as temperature, $\mathrm{pH}$ or water residence time (Lindstrom et al. 2005). Since the discovery of high viral abundance in aquatic ecosystems, virioplankton in particular have 
come to be regarded as key players in aquatic ecosystems, and there is strong interest in characterizing the roles of viruses in aquatic food webs and in driving aquatic microbial dynamics (Fuhrman 1999, Miki et al. 2008).

Viral lysis can be a major cause of bacterial mortality in freshwaters, accounting for up to $100 \%$ of bacterial biomass turnover (Weinbauer \& Hofle 1998, Sime-Ngando \& Ram 2005, Jacquet et al. 2007, Simek et al. 2007, Berdjeb et al. 2011). This has important implications in the microbial dynamics of freshwater ecosystems. If viruses are host-specific, it would be expected that changes in viral community composition would reflect seasonal patterns of change in their host communities. As bacterial species increase in abundance, the contact rate between virus and host increases, leading to higher infection rates and eventual decline of the dominant host species (Thingstad 2000, Miki et al. 2008). It is likely that the majority of aquatic viruses are bacteriophages that infect heterotrophic bacteria (Wommack \& Colwell 2000). However, the relationships between aquatic viral assemblages, autotrophs (both eukaryotic algae and cyanobacteria) and heterotrophic bacterioplankton vary across studies, and seasonal changes in viral abundance and community composition may not reflect those of bacterial heterotrophs in all aquatic ecosystems (Clasen et al. 2008).

Relatively little is known regarding temporal change in viral community composition in fresh waters. Change in viral community composition in marine ecosystems has been characterized over spatial and temporal scales using pulsed-field gel electrophoresis (PFGE) with a great deal of success (Wommack et al. 1999, Steward et al. 2000, Fuhrman et al. 2002, Riemann \& Middelboe 2002, Jiang et al. 2003, Hewson et al. 2006, Parada et al. 2008). Despite its wide use, PFGE is not without its drawbacks. In particular, its high limit of detection necessitates concentration of viruses from large sample volumes, in some cases, up to 801 (Wommack et al. 1999). In freshwaters, a few studies have explored the dynamics of specific viruses and their hosts (e.g. Hewson et al. 2011, Short et al. 2011), and a handful of studies have used PFGE to examine changes in total virioplankton community composition (Auguet et al. 2006, Filippini \& Middelboe 2007, Tijdens et al. 2008). However, a qualitative comparison of existing studies shows that PFGE band richness and resolution is much poorer for freshwater samples than for marine samples.

Randomly amplified polymorphic DNA (RAPD) polymerase chain reaction (PCR) has recently been developed as an alternative means for fingerprinting marine viral communities (Winget \& Wommack 2008, Helton \& Wommack 2009, Winter \& Weinbauer 2010) and holds several advantages over PFGE in the analysis of virioplankton community composition. In particular, RAPD-PCR generates more bands per sample than PFGE, increasing the likelihood of detecting changes in viral community composition. However, to our knowledge, RAPD-PCR has not yet been applied to the characterization of freshwater viral assemblages.

The main goals of the present work were to improve understanding of microbial dynamics and to identify potential drivers of seasonal changes in virio- and bacterioplankton community composition in freshwater ecosystems. To accomplish this goal, an initial task was to develop and optimize viral concentration procedures for analyzing changes in freshwater viral community composition using RAPD-PCR. Once optimized, RAPD-PCR was used in a $18 \mathrm{mo}$ field study to examine temporal changes in viral community composition in a temperate eutrophic freshwater lake (Lake Matoaka), with co-variance in the bacterioplankton community quantified using terminal restriction fragment length polymorphism (tRFLP).

\section{MATERIALS AND METHODS}

\section{Study site and sample collection}

Lake Matoaka is a 16 ha freshwater (salinity $\geq 0.2 \mathrm{ppt}$ ) impoundment located on the campus of the College of William and Mary in Williamsburg, VA (Pensa \& Chambers 2004). Its average depth is $2.5 \mathrm{~m}$ (max. depth $4.57 \mathrm{~m}$ ), and the water residence time is $75 \mathrm{~d}$ (turnover $1.3 \% \mathrm{~d}^{-1}$ ). The lake is fed by 3 main tributaries (College Creek, Pogonia Creek and Strawberry Creek) and discharges into the James River and ultimately the Chesapeake Bay. For analysis of seasonal change in the microbial community, water samples were collected at a boat-launch pier adjacent to the Keck Environmental Field Laboratory $\left(37^{\circ} 16^{\prime} 13.7^{\prime \prime} N\right.$, $\left.76^{\circ} 43^{\prime} 22^{\prime \prime} \mathrm{W}\right)$. Surface samples $(<1 \mathrm{~m}$, collected by hand in polypropylene carboys) were collected monthly from May 2009 to November 2011, with the exceptions of May 2010 and January 2011.

For the comparison of virioplankton concentration methods, surface water samples were collected at the Lake Matoaka Inlet ( $\left.37^{\circ} 16^{\prime} 31.9^{\prime \prime} \mathrm{N}, 76^{\circ} 43^{\prime} 27.4^{\prime \prime} \mathrm{W}\right)$, Pier and Spillway $\left(37^{\circ} 15^{\prime} 49.1^{\prime \prime} \mathrm{N}, 76^{\circ} 43^{\prime} 20.3^{\prime \prime} \mathrm{W}\right)$. For samples collected from March 2009 through July 
2009, viral community composition was analyzed using PFGE. For samples collected from August 2009 through November 2010, analysis of viral community composition was performed using RAPD-PCR. To compare results of RAPD-PCR with marine versus freshwater samples, marine surface samples (salinity 22 ppt) were collected from the Chesapeake Bay (Gloucester Point, VA; 37 14' 51.2" N, 76³0' 01.6" W) on 7 March 2011 and 10 June 2011.

\section{Viral and bacterial abundance}

Water samples $(2 \mathrm{ml})$ were dispensed into cryovials, flash frozen in liquid nitrogen and stored at $-80^{\circ} \mathrm{C}$ until processing (Wen et al. 2004). Viral and bacterial abundance were determined based on methods devised by Noble \& Fuhrman (1998). Aliquots (100 to $200 \mu \mathrm{l}$ ) of thawed water samples were suspended in $1 \mathrm{ml}$ total volume in sterile Milli$\mathrm{Q}$ water, loaded onto a $25 \mathrm{~mm}, 0.02 \mu \mathrm{m}$ pore-size Anodisc (Whatman) and drawn through the filter under vacuum. Anodiscs were stained with $100 \mu \mathrm{l}$ of $2.5 \times$ SYBR Gold (diluted from $10000 \times$ stock; Invitrogen) in the dark for $15 \mathrm{~min}$. After drawing off the stain, the Anodiscs were air-dried and mounted onto a glass slide using a drop of antifade $(50 \mathrm{mg} p$ phenylene diamine; $2 \mathrm{ml}$ of $1 \times \mathrm{PBS}_{;} 2 \mathrm{ml} 1.0 \mathrm{M}$ Tris, $\mathrm{pH} 8.0 ; 46 \mathrm{ml} 80 \%$ glycerol).

Bacterial cells and virus particles were visualized using an Olympus BX-51 microscope outfitted with a mercury arc lamp and a fluorescein isothiocyanate filter. A total of 10 to 20 digital photographs (>200 cells and 200 virus particles per sample) were taken for each raw water sample using a Hamamatsu CCD camera. Bacterial and viral abundances were determined using the Metamorph Basic software package (Olympus).

\section{Water chemistry and chlorophyll a}

Temperature was measured using a standard mercury thermometer at the time samples were taken. The $\mathrm{pH}$ was measured in the laboratory using an UltraBasic $\mathrm{pH}$ meter (Denver Instruments). Nutrient levels $\left(\mathrm{NO}_{2}+\mathrm{NO}_{3}, \mathrm{NH}_{4}\right.$ and $\left.\mathrm{PO}_{4}\right)$ were determined using colorimetric assays with water filtered through Whatman glass fiber filters (GF/F) (Parsons et al. 1984). Chlorophyll a (chl a) was determined spectrophotometrically (Lorenzen 1967). Briefly, $250 \mathrm{ml}$ of whole water was filtered through $47 \mathrm{~mm}$ diameter Whatman GF/F filters. Filters were extracted with
$90 \%$ acetone for $24 \mathrm{~h}$ at $4^{\circ} \mathrm{C}$ before reading absorbance in a Genesys 20 spectrophotometer (Thermo-Spectronic). Calculations were corrected for the presence of phaeopigments. Monthly rainfall data was obtained from the Williamsburg Government website: www.williamsburgva.gov/Index.aspx? page $=242$.

\section{Bacterioplankton processing}

Surface water samples (6 l) were pre-filtered through a $10 \mu \mathrm{m}$ capsule filter (GeoTech Environmental) to remove debris, followed by a series of $142 \mathrm{~mm}$ diameter nylon filters: a $5 \mu \mathrm{m}$ and $3 \mu \mathrm{m}$ filter (Pall) were used to remove protozoa, zooplankton and phytoplankton. Bacterioplankton were captured on a $0.22 \mu \mathrm{m}$ ExpressPlus membrane filter (Millipore). The filters were folded, placed in sterile Falcon tubes and stored at $-80^{\circ} \mathrm{C}$ until DNA extraction (Rusch et al. 2007).

\section{Comparison of viral concentration methods}

To compare the impact of concentration factor on viral fingerprints obtained by RAPD-PCR, aquatic viruses were concentrated by 3 different methods.

201 tangential flow filtration. Samples were processed similar to the method used by Suttle et al. (1991). Surface water samples were collected in $20 \mathrm{l}$ polypropylene carboys and pre-filtered through $10 \mu \mathrm{m}$ capsule filters (GeoTech Environmental). Bacteria were removed using a $0.22 \mu \mathrm{m}$ tangential flow filtration (TFF) cartridge (Pall Life Sciences Centramate PSM20C11, $\left.1 \mathrm{ft}^{2}\left[0.093 \mathrm{~m}^{2}\right]\right)$. Virus particles in the $0.22 \mu \mathrm{m}$ filtrate were concentrated using a $30 \mathrm{kDa}$ TFF cartridge (Millipore Prep/Scale CDUF006LT, $6 \mathrm{ft}^{2}\left[0.557 \mathrm{~m}^{2}\right]$ ) to a volume of $\sim 100 \mathrm{ml}$. This primary concentrate was further concentrated using centrifugal filtration devices (Millipore Centricon Plus 70, $30 \mathrm{kDa} \mathrm{MWCO}$ ) to a volume of $\sim 2 \mathrm{ml}$ (Winget \& Wommack 2008). The final viral concentrate was washed 3 times with $50 \mathrm{ml}$ TMG buffer $(10 \mathrm{mM}$ Tris$\mathrm{Cl}, 10 \mathrm{mM} \mathrm{MgSO}_{4}$ and $1 \% \mathrm{w} / \mathrm{v}$ gelatin), and sodium azide was added $(0.1 \%$ final conc.) to inhibit growth of any potential bacterial contamination. Viral concentrates were stored at $4^{\circ} \mathrm{C}$.

61 tangential flow filtration. Surface water samples were collected and pre-filtered as described above. To remove bacteria, water was filtered through a series of $142 \mathrm{~mm}$ diameter membranes of decreasing pore size as described above (Rusch et al. 2007). Virus 
particles in the $0.22 \mu \mathrm{m}$ filtrate were concentrated using a $30 \mathrm{kDa}$ TFF cartridge (Millipore Prep/Scale CDUF006LT, $\left.6 \mathrm{ft}^{2}\left[0.557 \mathrm{~m}^{2}\right]\right)$ to a volume of $\sim 100 \mathrm{ml}$ (Suttle et al. 1991) and further concentrated using centrifugal filtration devices as described above. The final viral concentrate was washed 3 times with $50 \mathrm{ml}$ TMG buffer and stored as above.

$50 \mathbf{~ m l}$ ultracentrifugation. Surface water samples were collected using a sterile $50 \mathrm{ml}$ Falcon tube and filtered through a $0.22 \mu \mathrm{m}$ Sterivex syringe filter (Millipore) into polyallomer ultracentrifuge tubes (Beckman). Samples were spun at $22000 \mathrm{rpm}$ (82 000 $\times g$ ) for $2 \mathrm{~h}$ at $4^{\circ} \mathrm{C}$ in a Beckman SW41Ti rotor. Supernatants were carefully decanted to avoid disturbing viral pellets, and the pellets were resuspended in $20 \mu \mathrm{l}$ of TMG buffer and combined in a sterile $1.5 \mathrm{ml}$ microcentrifuge tube. Viral concentrates were amended with azide and stored as above.

\section{Analysis of viral community composition by PFGE}

Agarose plugs were prepared by mixing $40 \mu \mathrm{l}$ $1.5 \%$ molten In-Cert agarose (Bio-Rad) with $40 \mu \mathrm{l}$ of viral concentrate, diluted such that each plug contained $2 \times 10^{9}$ virus particles. The mixture was dispensed into $80 \mathrm{cc}$ plastic plug molds and allowed to solidify at $4^{\circ} \mathrm{C}$ for $30 \mathrm{~min}$. Plugs were then released from molds into $2 \mathrm{ml}$ of digestion buffer $(250 \mathrm{mM}$ EDTA, $1 \% \mathrm{SDS}, 10 \mathrm{mg} \mathrm{ml}^{-1}$ proteinase $\mathrm{K}$ ) and incubated overnight at $37^{\circ} \mathrm{C}$. The digestion buffer was carefully decanted, and the plugs were washed 3 times, 30 min each, with $1 \times$ TE buffer $(10 \mathrm{mM}$ Tris$\mathrm{Cl}, 1 \mathrm{mM}$ EDTA, pH 8.0) and stored at $4^{\circ} \mathrm{C}$ in $2 \times \mathrm{TE}$ buffer (Wommack et al. 1999).

PFGE was performed with a CHEF DR-II system (Bio-Rad) using Mid-Range PFG molecular weight markers (New England BioLabs). Plugs containing virus concentrates and molecular weight markers were loaded into a $0.8 \%$ pulsed-field certified agarose gel and overlaid with $1.5 \%$ molten In-Cert agarose (Bio-Rad). Electrophoresis was carried out in $0.5 \times \mathrm{TBE}$ buffer at $14^{\circ} \mathrm{C}$ and $6 \mathrm{~V} \mathrm{~cm}^{-1}$ under the following conditions: initial switch time $0.3 \mathrm{~s}$, final switch time $6.5 \mathrm{~s}$, total run time $19 \mathrm{~h}$ and included angle $120^{\circ}$ (Wommack et al. 1999, Steward 2001)

Gels were stained with $1 \times$ SYBR Gold (diluted from $10000 \times$ stock) in $0.5 \times \mathrm{TBE}$ buffer for $1 \mathrm{~h}$ prior to visualization of bands using a Kodak Gel Logic 100 imaging system (Eastman-Kodak). Banding patterns were analyzed using ImageQuant TL software (v.2003, GE Life Sciences) and converted to binary matrix format.

\section{Analysis of viral community composition by RAPD-PCR}

RAPD-PCR reactions were set up using primer CRA-22 (5'-CCG CAG CCA A-3'), and thermocycler conditions were programmed as described by Winget \& Wommack (2008). A $1 \mu$ l virus concentrate, diluted to contain $10^{5}$ virus particles, was used as a template in each reaction, as tests of viral template concentration suggested inhibition at higher concentrations and over-dilution of template at lower concentrations, as each scenario resulted in a reduction in band richness (see Fig. S1 in the supplement at www.int-res.com/articles/suppl/a067p059 _supp.pdf).

To assess the potential contribution of non-viral DNA to RAPD-PCR products, a subset of viral concentrates was subjected to DNase treatment prior to RAPD-PCR amplification. DNase reaction mixtures contained 1 U of RQ1 RNase-free DNase (Promega), $1 \times$ DNase buffer (final conc.), $1 \mu$ l of viral concentrate and diethyl pyrocarbonate-treated water to a final volume of $20 \mu \mathrm{l}$. Reaction mixtures were incubated for $30 \mathrm{~min}$ at $37^{\circ} \mathrm{C}$ followed by $15 \mathrm{~min}$ at $65^{\circ} \mathrm{C}$. Aliquots $(1 \mu \mathrm{l})$ from each of these reactions served as template DNA in RAPD-PCR reactions, and the results were compared to those from non-DNasetreated but similarly diluted (1:20 in diethyl pyrocarbonate-treated water) viral concentrate.

For all reactions, RAPD-PCR products from the complete $25 \mu \mathrm{l}$ reaction were separated by gel electrophoresis on $13 \times 16 \mathrm{~cm} 1.8 \%$ GenePure HiRes agarose gels (ISC BioExpress) in $0.5 \times$ TBE buffer, run at $4 \mathrm{~V} \mathrm{~cm}^{-1}$. Gels were stained with $1 \times$ SYBR Safe (Invitrogen) in $0.5 \times \mathrm{TBE}$ buffer for $1 \mathrm{~h}$ prior to visualization of bands using a Kodak Gel Logic 100 imaging system. Banding patterns were analyzed using ImageQuant TL software to perform densitometry analysis and converted to binary matrix format. Cluster analysis (Dice coefficient) was used to construct a dendrogram following unweighted pair group method with arithmetic means.

\section{Bacterial DNA extraction}

Bacterial genomic DNA was extracted from cells captured on the $0.22 \mu \mathrm{m}$ filters using methods adapted from Rusch et al. (2007), with the following modifications. After cell lysis, crude DNA extracts were precipitated with isopropanol and transferred to $1.5 \mathrm{ml}$ tubes. The DNA was then purified using phenol/chloroform extraction on a smaller scale in 
the $1.5 \mathrm{ml}$ tubes. After precipitating purified DNA with isopropanol and washing with $70 \%$ ethanol, DNA pellets were resuspended in $50 \mu \mathrm{l}$ of $1 \times \mathrm{TE}$ Buffer. DNA was quantified using a NanoDrop ${ }^{\circledR}$ 1000 Spectrophotometer (Thermo Scientific) and stored at $-20^{\circ} \mathrm{C}$ until use.

\section{S rRNA PCR and purification of PCR products}

A fragment of the 16S rRNA gene was amplified by PCR for each sample. Primers were obtained from Integrated DNA Technologies and included 519r (5'-GWA TTA CCG CGG CKG CTG-3') and 27f-HEX (5'-HEX-AGA GTT TGA TCC TGG CTC AG-3') (Lane 1991). PCR products were then run on a $0.8 \%$ agarose in $1 \times$ TAE Buffer at $90 \mathrm{~V}$ for $1 \mathrm{~h}$. Following the run, gels were stained in $400 \mathrm{ml}$ of $1 \times$ TAE buffer with $25 \mu$ of $10000 \times$ SYBR Safe (Invitrogen) in the dark at $22^{\circ} \mathrm{C}$ for $1 \mathrm{~h}$. Gels were visualized using a Kodak Gel Logic 100 Imaging System with Kodak Molecular Imaging Software (Eastman-Kodak). PCR products from 4 replicate reactions per sample were pooled and purified using a QIAquick PCR purification kit (Qiagen).

\section{tRFLP analysis}

Bacterial community composition was characterized using tRFLP based on 2 different restriction enzymes (HinfI and MspI) to generate a profile of the bacterial community in the lake and to track changes over time (Lymer et al. 2008b). The reproducibility of the tRFLP data was measured by running 5 different samples in duplicate using the Hinf I enzyme. Cluster dendrograms showed that replicate restriction digests of pooled 16S rRNA-PCR amplicons generated highly similar ( $\geq 90 \%$ ) T-RF patterns (see Fig. S2 in the supplement).

To remove terminal overhangs on HEX-labeled 16S rRNA gene amplicons, purified PCR products were treated with $1 \mu \mathrm{l}$ of mung bean nuclease (New England BioLabs) for $30 \mathrm{~min}$ at $37^{\circ} \mathrm{C}$. The mung bean nuclease was removed by phenol/ chloroform extraction. DNA was precipitated with ethanol, and the pellet was resuspended in $60 \mu \mathrm{l}$ of sterile de-ionized water. Aliquots of the mung bean nuclease-treated DNA were digested overnight at $37^{\circ} \mathrm{C}$ with either Hinf I or MspI (New England BioLabs). Restriction enzymes were removed using phenol/chloroform extraction, and the DNA was precipitated with ethanol and resuspended in sterile de-ionized water (Liu et al. 1997, Lymer et al. 2008b).

A mixture of $12 \mu \mathrm{l}$ of HI-DI formamide and $0.25 \mu \mathrm{l}$ of 500-ROX size standard (Applied Biosystems) were added to the restriction fragments, which were then loaded in a 96 well plate for analysis in an ABI3130 Avant Gene Sequencer (Applied Biosystems) with Pop7 polymer. Each run was performed in a $36 \mathrm{~cm}$ capillary with dye set DS-30 (ROX, 6FAM, HEX and NED) as a matrix standard. The resulting chromatograms from the above gene fragment analysis were analyzed using GeneMapper Software Version 4.0 (Applied Biosystems). Replicate tRFLP runs were aligned by manual inspection of peak shift. Peak thresholds were set using a minimum peak height of 50 fluorescence units. The light-smoothing algorithm available in the GeneMapper software was applied to the peaks to reduce background noise or artifacts in peak detection. Peaks were sorted into bins of 1 to 50 base pairs, and the data from each chromatogram were converted to presence/absence matrices.

\section{Statistical analyses}

All environmental data were log-transformed to obtain normal distributions. To test for relationships between bacterial and viral richness, bacterial and viral abundance, and environmental data, Pearson's correlation analysis and Bonferroni post-tests were performed in Prism 5 (GraphPad Software). The presence/absence matrix data for the bacterial Hinf I and MspI tRFLP profiles and viral RAPD profiles were converted into similarity matrices (Dice similarity coefficient) and analyzed by non-metric multidimensional scaling (NMDS) in PAST (Hammer et al. 2001). This type of ordination analysis was used to identify overarching patterns that may help explain similarities (or dissimilarities) across samples. In essence, the closer 2 samples are to each other in the NMDS plot, the more similar their community composition (as determined by RAPD banding pattern); the further away 2 samples are, the more dissimilar. BioEnv tests (Clarke \& Ainsworth 1993) were performed using the vegan package in $\mathrm{R}$ (Version 2.12.1; R Development Core Team 2012) to identify potential environmental factors that best explain shifts in both bacterial and viral community composition. To test for co-variance between bacterial (HinfI and MspI profiles) and viral community profile shifts, Mantel statistics were computed in $\mathrm{R}$ based on Spearman rank correlation and 9999 random permutations. 
Table 1. Chemical, environmental, and community data for Lake Matoaka from May 2009 to November 2010. Chl a: chloro-

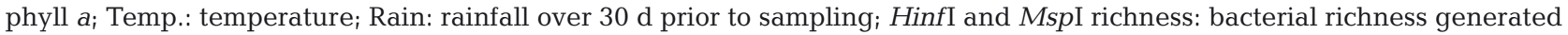
through tRFLP with either HinfI or MspI restriction digests. BDL: below detection limit ( $>0.05 \mu \mathrm{M})$; nd: not determined

\begin{tabular}{|c|c|c|c|c|c|c|c|c|c|c|}
\hline Date & $\begin{array}{c}\text { Chl a } \\
\left(\mu \mathrm{g} \mathrm{l}^{-1}\right)\end{array}$ & $\begin{array}{c}\text { Temp. } \\
\left({ }^{\circ} \mathrm{C}\right)\end{array}$ & $\mathrm{pH}$ & $\begin{array}{c}\mathrm{NO}_{2}+\mathrm{NO}_{3} \\
(\mu \mathrm{M})\end{array}$ & $\begin{array}{l}\mathrm{NH}_{4} \\
(\mu \mathrm{M})\end{array}$ & $\begin{array}{l}\mathrm{PO}_{4} \\
(\mu \mathrm{M})\end{array}$ & $\begin{array}{l}\text { Rain } \\
(\mathrm{mm})\end{array}$ & $\begin{array}{c}\text { Viral } \\
\text { richness }\end{array}$ & $\begin{array}{c}\text { Hinf I } \\
\text { richness }\end{array}$ & $\begin{array}{c}\text { MspI } \\
\text { richness }\end{array}$ \\
\hline 5 May 2009 & nd & nd & nd & 5.77 & 3.04 & 1.48 & nd & nd & 20 & 27 \\
\hline 2 Jun 2009 & 9.19 & 27.0 & 7.2 & 1.10 & BDL & 0.60 & 134.9 & nd & 37 & 39 \\
\hline 6 Jul 2009 & 15.44 & 27.5 & 7.87 & 0.00 & 0.25 & 0.00 & 89.9 & 27 & 19 & 17 \\
\hline 4 Aug 2009 & 69.15 & 29.5 & 7.88 & 23.25 & BDL & 0.84 & 191.5 & 26 & $25^{\mathrm{a}}$ & 27 \\
\hline 8 Sep 2009 & 3.70 & 25.1 & 7.83 & 27.98 & $\mathrm{BDL}$ & 0.80 & 100.1 & 23 & $27^{\mathrm{a}}$ & 9 \\
\hline 6 Oct 2009 & 7.93 & 21.0 & 8.01 & nd & nd & nd & 172.0 & 20 & 12 & 9 \\
\hline 3 Nov 2009 & 1.54 & 13.5 & 7.07 & 4.45 & 0.29 & 0.94 & 76.5 & 23 & $16^{\mathrm{a}}$ & 10 \\
\hline 8 Dec 2009 & 6.73 & 8.5 & 7.19 & 6.31 & 2.84 & 0.53 & 185.4 & 20 & $24^{\mathrm{a}}$ & 33 \\
\hline 17 Feb 2010 & 12.10 & 5.0 & 7.43 & 13.46 & 0.28 & 0.56 & 126.2 & 11 & $36^{\mathrm{a}}$ & 35 \\
\hline 9 Mar 2010 & 9.98 & 11.5 & 7.56 & 18.39 & BDL & 1.07 & 26.7 & 27 & 7 & 7 \\
\hline 6 Apr 2010 & 3.90 & 18.2 & 7.43 & 7.06 & BDL & 0.41 & 156.0 & 23 & 7 & 7 \\
\hline 8 Jun 2010 & 13.77 & 26.5 & 7.04 & 4.35 & 2.05 & 0.31 & 73.7 & 23 & $27^{a}$ & 28 \\
\hline 7 Jul 2010 & 20.80 & 27.1 & 7.14 & 3.14 & 15.16 & 0.46 & 46.7 & 25 & 9 & 4 \\
\hline 3 Aug 2010 & 15.99 & 27.0 & 6.96 & 4.89 & 9.77 & 0.36 & 81.3 & 22 & 4 & 10 \\
\hline 1 Sep 2010 & 10.80 & 30.1 & 7.59 & 1.30 & 10.32 & 0.41 & 59.4 & 21 & 40 & 48 \\
\hline 4 Oct 2010 & 10.80 & 22.0 & 7.1 & 29.76 & 77.57 & 1.77 & 360.4 & 23 & 42 & 27 \\
\hline 10 Nov 2010 & 0.32 & 15.0 & 7.36 & 54.31 & 6.14 & 1.15 & 122.2 & 28 & 33 & 32 \\
\hline
\end{tabular}

\section{RESULTS}

\section{Water chemistry}

The surface water temperature of Lake Matoaka was highest in August 2009 and September 2010 and lowest in December 2009 and February 2010, when a thin layer of ice covered shallower sections of the lake (Table 1). Chl a levels were highest in the summer months, with maxima in August 2009 and July 2010, corresponding with abundant algal biomass in the lake. Levels of dissolved nitrogen compounds also appeared to follow a cyclical trend and were highest in August and September 2009 and October and November 2010. Dissolved inorganic phosphate levels varied only slightly over the sample period, averaging $0.73 \mu \mathrm{M}$. The $\mathrm{pH}$ varied between 6.96 and 8.01 over the 18 mo observation period, with an average value of 7.45.

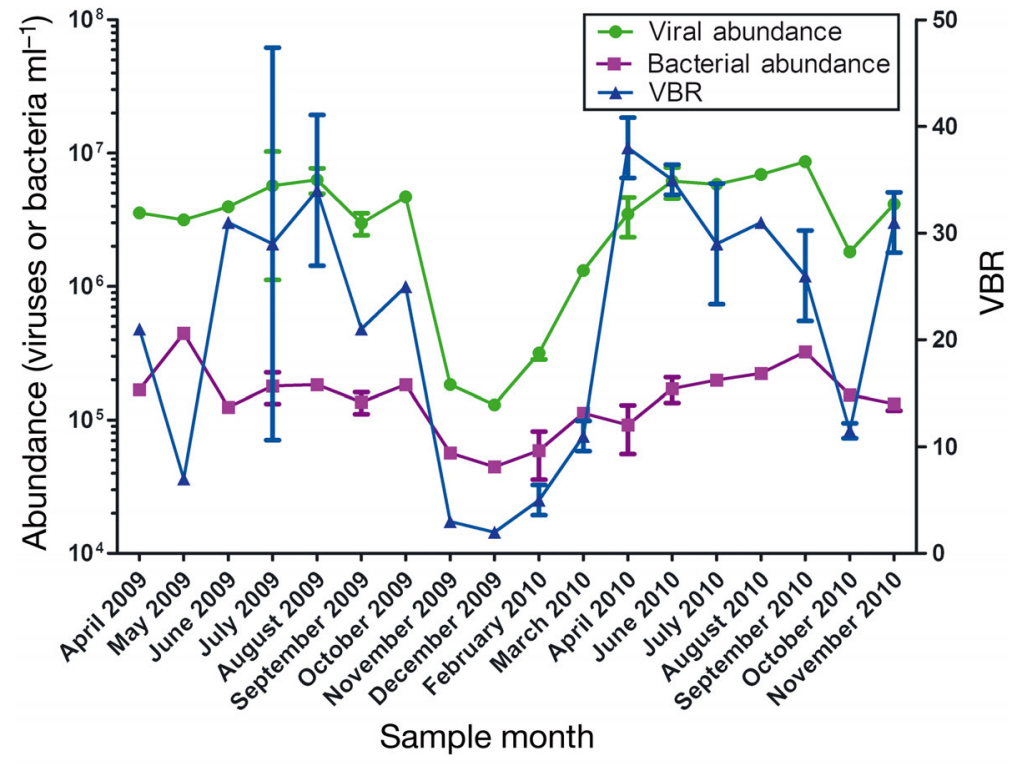

Fig. 1. Mean viral abundance, bacterial abundance, and virus-tobacterium ratio (VBR) in Lake Matoaka during 2009 and 2010. Error bars indicate SD $(n=3)$

\section{Bacterial and viral abundance}

Bacterial and viral abundance in Lake Matoaka followed a cyclical trend over the 18 mo sampling period (Fig. 1). Viral abundance was consistently higher than bacterial abundance by a factor of $\sim 30$. Both viral and bacterial abundance were highest in the summer months and lowest in the winter months. Abundance decreased drastically between the summer and winter of 2009. However, this pattern of sharp decrease in abundance trends was not observed between the summer and winter of 2010. Viral abundance and bacterial abundance were significantly correlated $\left(\mathrm{r}=0.932 ; \mathrm{p}=4.21 \times 10^{-7}\right.$; Table 2$)$ 
Table 2. Pearson correlations between microbial abundance, richness and environmental data. VA: viral abundance; BA: bacterial abundance; Chl a: chlorophyll a concentration; Temp.: temperature; rain: monthly rainfall; Vrich: viral richness; hinRich: bacterial richness based on HinfI profile; mspRich: bacterial richness based on MspI profile. Where statistically significant ( $p$ $<0.05)$, p-values are given in parentheses. p-values associated with all correlations are provided in Table S1 in the supplement at www.int-res.com/articles/suppl/a067p059_supp.pdf

\begin{tabular}{|c|c|c|c|c|c|c|c|c|c|c|c|c|}
\hline Variable & VA & $\mathrm{BA}$ & Chl a & Temp. & $\mathrm{pH}$ & $\mathrm{NO}_{2}+\mathrm{NO}_{3}$ & $\mathrm{NH}_{4}$ & $\mathrm{PO}_{4}$ & Rain & Vrich & \multicolumn{2}{|c|}{ hinRich mspRich } \\
\hline VA & 1 & & & & & & & & & & & \\
\hline BA & $\begin{array}{c}0.932 \\
\left(4.2 \times 10^{-7}\right)\end{array}$ & 1 & & & & & & & & & & \\
\hline Chl a & 0.354 & 0.349 & 1 & & & & & & & & & \\
\hline Temp. & $\begin{array}{c}0.868 \\
\left(2.6 \times 10^{-6}\right)\end{array}$ & $\begin{array}{c}0.857 \\
\left(4.5 \times 10^{-6}\right.\end{array}$ & 0.242 & 1 & & & & & & & & \\
\hline $\mathrm{pH}$ & 0.316 & 0.263 & -0.081 & 0.175 & 1 & & & & & & & \\
\hline $\mathrm{NO}_{2}+\mathrm{NO}_{3}$ & -0.343 & -0.414 & 0.224 & -0.328 & -0.158 & 1 & & & & & & \\
\hline $\mathrm{NH}_{4}$ & 0.349 & 0.503 & 0.274 & 0.423 & -0.417 & 0.014 & 1 & & & & & \\
\hline $\mathrm{PO}_{4}$ & -0.267 & -0.196 & -0.201 & -0.127 & 0.327 & 0.347 & -0.127 & 1 & & & & \\
\hline Rain & -0.198 & -0.259 & -0.095 & -0.100 & 0.054 & 0.292 & 0.090 & 0.346 & 1 & & & \\
\hline Vrich & 0.401 & 0.392 & 0.144 & $\begin{array}{c}0.665 \\
(0.006)\end{array}$ & -0.029 & 0.074 & 0.379 & 0.281 & -0.117 & 1 & & \\
\hline hinRich & -0.096 & 0.058 & 0.122 & -0.026 & 0.231 & 0.017 & 0.074 & 0.089 & 0.274 & -0.246 & 1 & \\
\hline mspRich & $\begin{array}{l}-0.104 \\
\left(4.5 \times 10^{-4}\right)\end{array}$ & 0.047 & 0.319 & -0.105 & 0.010 & -0.007 & 0.153 & -0.070 & 0.360 & -0.315 & 0.791 & 1 \\
\hline
\end{tabular}

Table 3. Effect of viral concentration method on concentration efficiency and viral richness. VC: viral abundance in final viral concentrate (virus $\mathrm{ml}^{-1}$ ). Efficiency: concentration efficiency determined by comparing final viral concentration to the theoretical yield based on viral abundance in the starting sample and VC volume. Bold values are highest. Richness: number of discrete bands generated by gel electrophoresis of RAPD-PCR products. Bold values are highest. UCF: ultracentrifugation of a $50 \mathrm{ml}$ water sample; 61 or $20 \mathrm{l} \mathrm{TFF}$ : tangential flow filtration of a 61 or 201 water sample, respectively; nd: not determined

\begin{tabular}{|c|c|c|c|c|c|c|c|c|c|}
\hline \multirow{2}{*}{ Sample } & \multicolumn{3}{|c|}{ UCF } & \multicolumn{3}{|c|}{$61 \mathrm{TFF}$} & \multirow{2}{*}{$\overline{\mathrm{VC}\left(10^{8}\right)}$} & $-201 \mathrm{TFF}$ & \multirow[b]{2}{*}{ Richness } \\
\hline & $\operatorname{VC}\left(10^{8}\right)$ & Efficiency & Richness & $\operatorname{VC}\left(10^{8}\right)$ & Efficiency & Richness & & Efficiency & \\
\hline LM March & 1.35 & $87.42 \%$ & 21-22 & 0.825 & $78.09 \%$ & $17-20$ & 0.224 & $78.33 \%$ & 18 \\
\hline CB March & 5.38 & $94.15 \%$ & 19 & 11.5 & $93.10 \%$ & 19 & 0.905 & $77.58 \%$ & 21 \\
\hline LM June & 17.3 & $94.88 \%$ & 18-19 & 5.69 & $78.65 \%$ & $15-16$ & 2.77 & $79.36 \%$ & $16-17$ \\
\hline CB June & 9.7 & nd & $17-18$ & 4.72 & nd & $15-16$ & 0.314 & nd & 16 \\
\hline
\end{tabular}

with each other. Both viral and bacterial abundance were significantly correlated with surface water temperature (viruses: $r=0.869, p=0.000026$; bacteria: $\mathrm{r}=0.857, \mathrm{p}=0.000045$; Table 2). However, none of the other measured parameters, including $\mathrm{pH}$, dissolved nutrients and chl $a$, were found to have biologically meaningful correlations with viral or bacterial abundances.

\section{Comparison of viral concentration methods}

To determine whether viral community profiles were sensitive to the manner in which viral concentrates (VC) are generated, 3 methods of virus concen- tration were compared: concentration from either 6 or 201 of water via TFF and concentration from $50 \mathrm{ml}$ of water via ultracentrifugation (UCF). The 61 TFFprocessed concentrates yielded the highest viral particle concentrations, followed by UCF concentrates and the $201 \mathrm{TFF}$ concentrates (Table 3). The concentration efficiency of each method (calculated by comparing the measured viral concentration to the theoretical viral yield based on viral abundance in the starting sample and final VC volume) was consistently highest for UCF and lowest for the $20 \mathrm{l} \mathrm{TFF}$ concentrates (Table 3). This may be partly due to poor recovery of virus particles adsorbed to filters. Alternatively, the increased processing times involved in TFF may expose viral particles to greater 

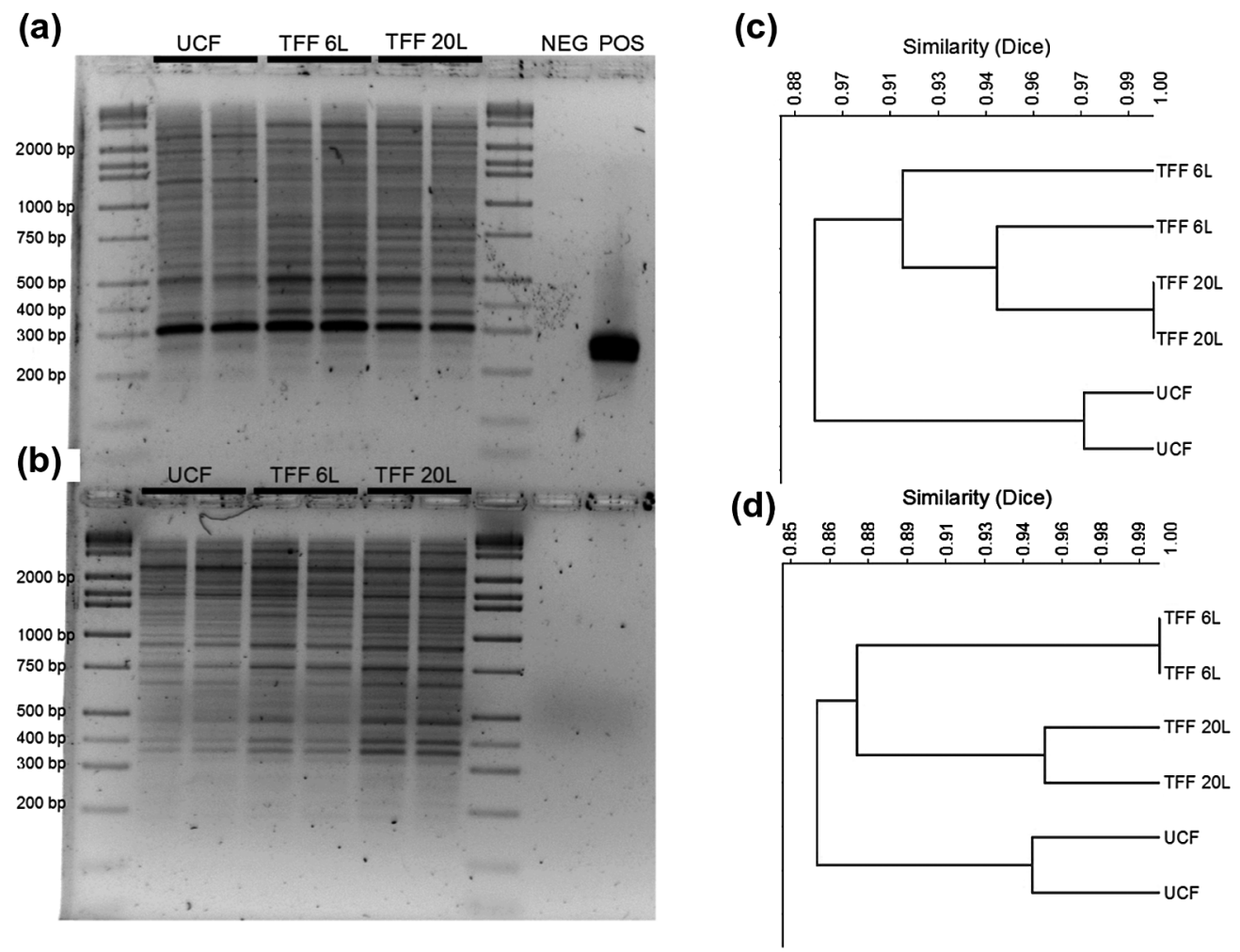

Fig. 2. Comparison of fingerprints from randomly amplified polymorphic DNA (RAPD) polmerase chain reaction (PCR) produced by different viral concentration methods in April 2011. UCF: ultracentrifugation of $50 \mathrm{ml}$ water sample; TFF 6 l: tangential flow filtration of 61 water sample; TFF 20 l: tangential flow filtration of 201 water sample. Left half shows gel electrophoresis of (a) Lake Matoaka and (b) Chesapeake Bay RAPD-PCR products; POS: positive control; NEG: template-free control; molecular weight markers are indicated in base pairs of DNA. Right half shows cluster dendrograms comparing the similarity (Dice method) of RAPD banding patterns across viral concentration methods for (c) Lake Matoaka and (d) Chesapeake Bay samples

physical agitation, increasing the likelihood of loss due to thermal decay. In UCF, these sources of loss are reduced as the viral particles are processed for $2 \mathrm{~h}$ at $4^{\circ} \mathrm{C}$.

\section{Assessment of virioplankton community composition by PFGE}

Change in viral community composition was initially assessed using PFGE from March 2009 to July 2009 for water sampled from 3 discrete locations in Lake Matoaka. However, the resulting bands (see Fig. S3 in the supplement) revealed very little change over time or space, when bands could be resolved. The high limit of detection for PFGE was identified as a key issue as the freshwater samples in the present study required at least $10^{9}$ virus particles per lane to resolve bands (see Fig. S4 in the supplement). These results prompted the further refinements in application of RAPD-PCR to study freshwater viral assemblages.

\section{Assessment of virioplankton community composition by RAPD-PCR}

To ensure that amplicons generated by RAPD-PCR originated from viral DNA templates and not from free DNA, several viral concentrates generated by UCF were subjected to DNase treatment (see Fig. S5 in the supplement). Addition of DNase resulted in negligible changes to banding patterns relative to untreated samples (83 to $93.6 \%$ similarity), indicating that RAPD templates did not originate from free DNA. To test the reproducibility of RAPD-PCR, all reactions were performed in duplicate. Banding patterns generated from duplicate reactions were on average $93 \%$ similar, ranging from 87 to $100 \%$ (Fig. 2; Fig. S6 in the supplement). Most differences arose from band binning as visual inspection of profiles revealed identical patterns in almost all cases.

RAPD-PCR of freshwater (Lake Matoaka) and marine (Chesapeake Bay) viral concentrates processed by each of the 3 concentration approaches successfully produced DNA amplicons. Unlike PFGE, RAPD- 


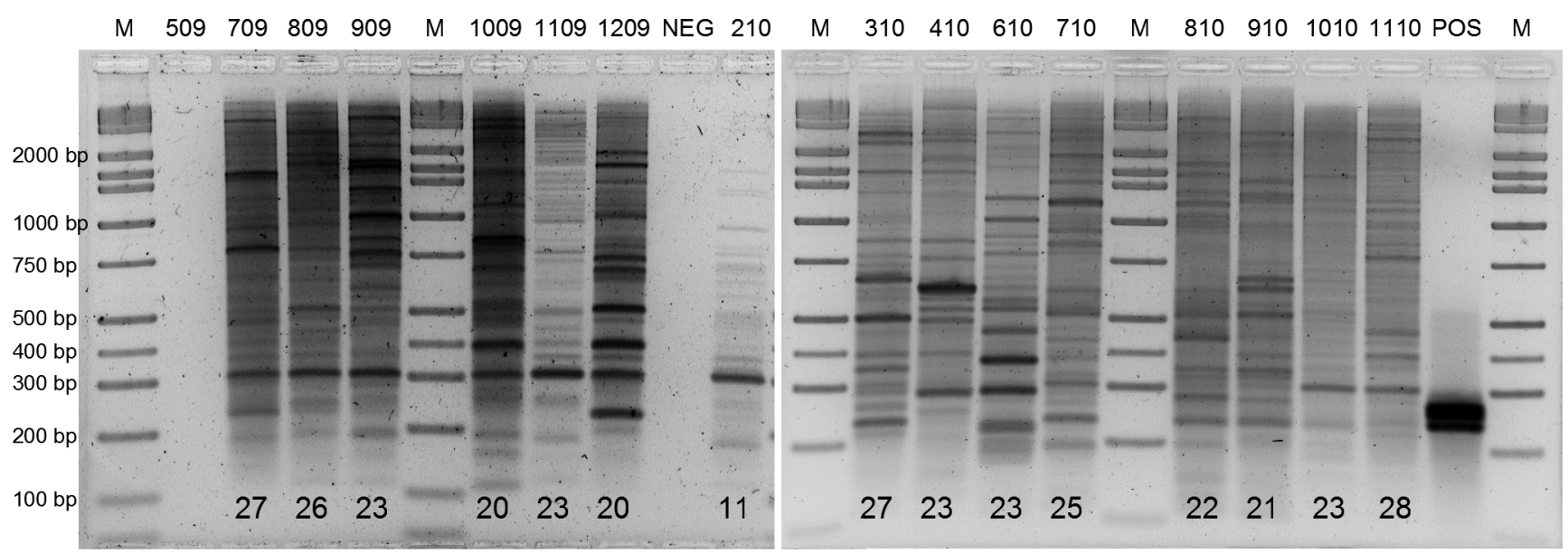

Fig. 3. Gel electrophoresis of RAPD-PCR products generated from Lake Matoaka viral concentrates over 2009 and 2010. Sampling dates are indicated at the top of each lane by month and year (e.g. $509=$ May 2009). Band richness is indicated at the bottom of each lane. M: molecular weight markers, sizes indicated in base pairs of DNA; POS: positive control; NEG: templatefree control

PCR produced distinct bands with as few as $10^{4}$ viruses per lane (e.g. Fig. 2b). Furthermore, RAPDPCR generated anywhere from 15 to 22 distinct bands per sample (Fig. 2, Table 3) compared to the 3 to 4 diffuse bands per sample typically generated by PFGE (see Fig. S3 in the supplement). In general, the UCF viral concentrates yielded the highest numbers of bands compared to corresponding 61 and $201 \mathrm{TFF}$ concentrates generated from the same samples (Table 3). The exception was the CB March 2011 sample, wherein the 201 TFF replicates had the highest number of bands at 21 compared to the other viral concentrates at 19 (Table 3). Comparison of RAPDPCR banding patterns generated from freshwater and marine viral concentrates revealed that the mean similarity between banding patterns produced by TFF and UCF viral concentrates for any given sample was $>85 \%$ (Fig. 2c,di Fig. S6 in the supplement).

\section{Seasonal change in Lake Matoaka viral community composition}

RAPD-PCR band richness varied between 11 (February 2010) and 28 (November 2011) distinct bands (Fig. 3). In 2009, the summer months (July and August) yielded the highest numbers of bands, with slightly decreasing band richness into winter, while in 2010, slight peaks in RAPD band richness were observed in March, July, and November (Fig. 3). With the exception of the low richness observed in February 2010, viral richness generally fluctuated between 20 and 28 bands during the 18 mo observation period. No significant relationship was observed between viral abundance and viral richness ( $\mathrm{r}=$ $0.401, \mathrm{p}=0.138$; Table 2). For example, viral richness in November 2009 was equal to that in June of 2010, despite the fact that viral abundance was $\sim 10$-fold higher in June than in November (Fig. 1). Pearson correlations revealed a weak relationship between viral richness and temperature $(\mathrm{r}=0.665 ; \mathrm{p}=0.007$; Table 2). However, no significant correlations were found between viral richness and any other measured environmental parameters (Table 2).

NMDS analysis of changes in RAPD banding patterns revealed an interesting pattern of monthly succession among the virioplankton in Lake Matoaka (Fig. 4). The viral community composition was fairly stable through the summer and fall of 2009, with the samples from July, August and October clustering tightly together and September and November forming another tight clustering. Through the winter and spring of 2010, the viral community composition underwent dramatic shifts (December 2009 and February and March 2010). The summer of 2010 also showed relatively large changes in viral community composition, evidenced by the distances between the April, June and July samples. These patterns suggest that the virioplankton community can be fairly static over monthly timescales (e.g. summer 2009) but that large and dramatic shifts are also possible over the same timescales (e.g. winter 2009 and 2010; Fig. 4).

BioEnv tests were performed to determine the relationships between the viral community composition data and the environmental data (Clarke \& Ainsworth 1993). This test was based on Dice dissimilarity matrices for the viral RAPD-PCR banding patterns and Euclidean distances of environmental data (Melo 


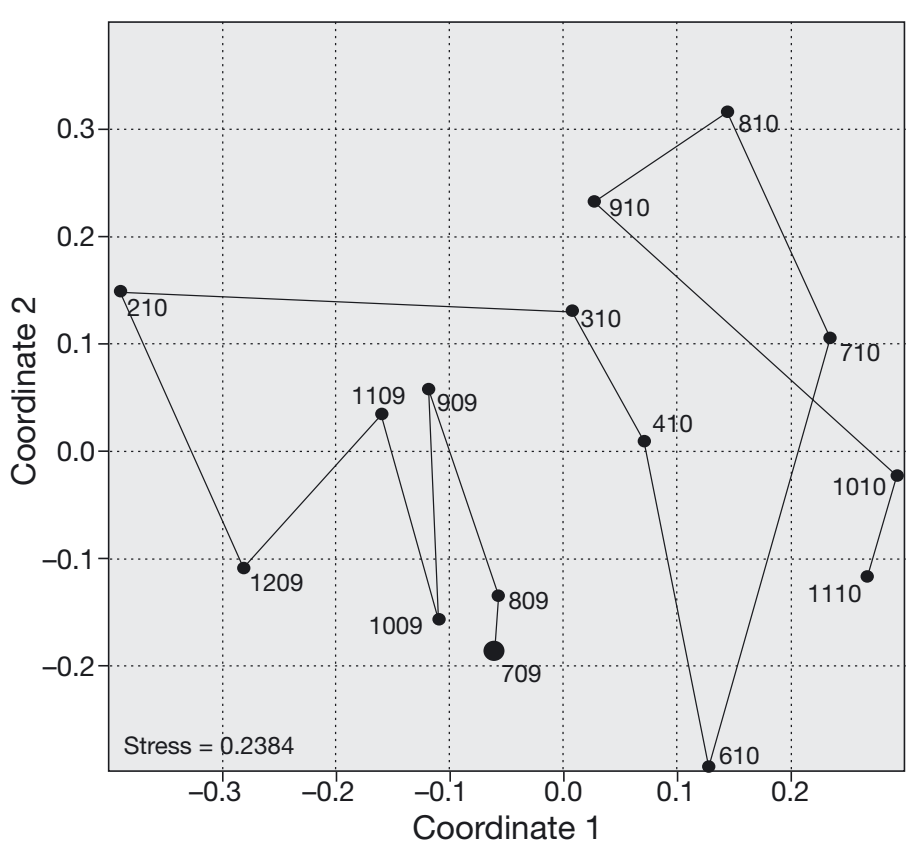

Fig. 4. Non-metric multidimensional scaling (NMDS) of viral community composition as determined from RAPD-PCR banding patterns based on Dice similarity coefficient. The larger filled circle (July 2009) indicates the first sampling date used in the analysis. Data points are coded by the month and year the sample was collected (e.g. 709 = July 2009)

2009) and identified environmental factors that best explain the variation observed in the biological data. The resulting Spearman rank correlations (r-statistics) are a measure of the explanatory power of an environmental variable in accounting for the variation in the biological (i.e. community composition) data. Results from BioEnv tests indicated that surface water temperature was the most important factor related to shifts in viral community composition. However, the Spearman rank correlation was only 0.5602 (see Table S2 in the supplement), suggesting that temperature is still not a particularly strong factor in driving viral community shift.

\section{Seasonal change in Lake Matoaka bacterial community composition}

Bacterial richness (number of tRFLP peaks) varied between 4 (July 2010, MspI profile) and 48 (September 2010, MspI profile) OTU. In general, bacterial richness as estimated from both Hinf I and MspI profiles showed peaks in midsummer of 2009, winter of 2010 and late fall of 2010 (Table 1). It is quite interesting that bacterial richness in the winter (February 2010) rivaled bacterial richness in the more productive summer months and that richness generally bottomed out in the late summer/early autumn. This perceived decrease in bacterial richness might be due to dominance by fewer bacterial species, whereas the increased richness in winter may actually be due to an increase in evenness among bacterial taxa in the lake. Bacterial richness data obtained from the HinfI and MspI tRFLP profiles were positively correlated with each other $(\mathrm{r}=0.791, \mathrm{p}=0.00045$; Table 2$)$. However, no significant correlations were found between bacterial richness and any of the measured environmental variables, including viral and bacterial abundance.

Analysis of bacterial profiles by NMDS revealed a dynamic pattern of bacterial community succession (Figs. $5 \& 6$ ), though little in the way of repeating annual patterns. Based on NMDS analysis of HinfI profiles, the bacterial community forms a fairly tight cluster from July through September of 2009 then undergoes a larger shift into the winter and maintains a looser clustering through early summer (November 2009 through June 2010). In the late summer and fall of 2010, the bacterial community appears to go through large shifts in composition each month (August through Novem-

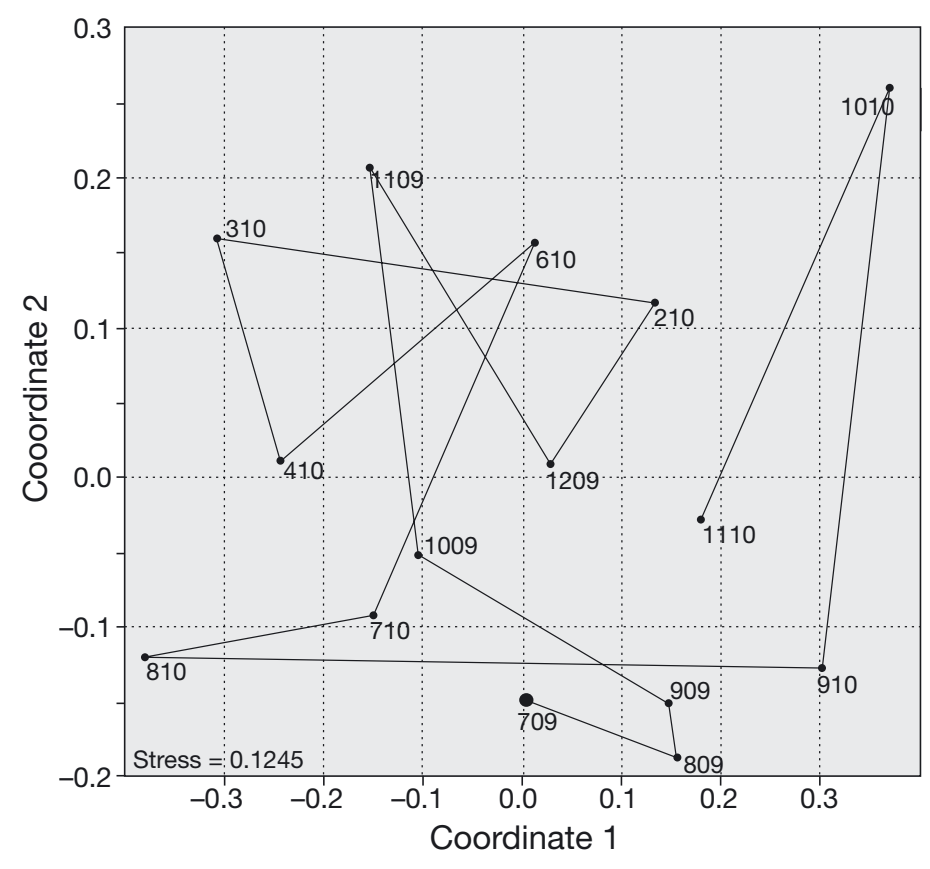

Fig. 5. NMDS of bacterial community composition as determined from Hinf I terminal restriction fragment length polymorphism (tRFLP) profile based on Dice similarity coefficient. See Fig. 4 legend for symbol and label key 


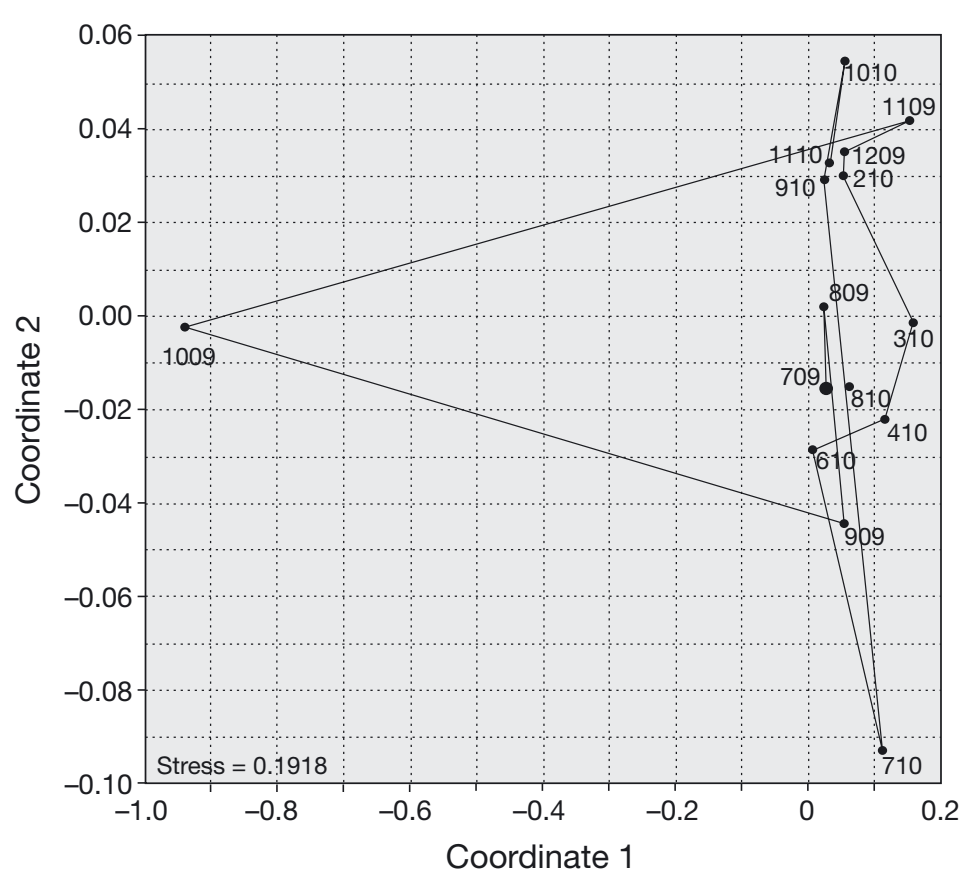

Fig. 6. NMDS of bacterial community composition as determined from MspI tRFLP profile based on Dice similarity coefficient. See Fig. 4 legend for symbol and label key

ber of 2010; Fig. 5). October 2010 appeared to be an outlier, shifted furthest away from all other samples in the NMDS plot. One potential explanation for this community shift is elevated rainfall in that month (360.4 mm; Table 1).

NMDS analysis based on MspI profiles revealed a different pattern of change, with a high degree of similarity between the bacterial communities observed in December 2009, February 2010, November 2010 and September 2010 (Fig. 6). This spread displays some degree of grouping based on season. The winter months of December 2009 and February 2010 form a tight group in the upper left of the NMDS plot. Samples from the summer, spring and fall months appear to be intermingled, though samples from the summer months (July and August of 2009 and June and August of 2010) form a fairly tight cluster (Fig. 6). October 2009 was an outlier in this data set, though it is difficult to determine the cause as there were no corresponding changes in rainfall, temperature, $\mathrm{pH}$, bacterial richness or other measured environmental factors during that month (Table 1). Results from BioEnv analysis indicated that temperature was the single best environmental factor for explaining the changes in bacterial community composition, with a Spearman rank correlation of 0.5676 and 0.5660 for the HinfI and MspI tRFLP patterns, respectively (see Table $\mathrm{S} 2$ in the supplement).

\section{Seasonal change in viral and bacterial community composition}

Mantel tests based on Spearman's rank correlation indicated that the composition of viral communities in Lake Matoaka was strongly and significantly correlated with bacterial community composition. Based on presence/absence of RAPD-PCR bands and tRFLP peaks, Dice similarity coefficients were calculated for viruses and bacteria, respectively. Mantel tests based on the resulting Dice similarity matrices yielded r-values of $0.9975(\mathrm{p}=0.0001)$ for HinfI-based bacterial community composition data and 0.9976 ( $\mathrm{p}=0.0001)$ for MspI-based data.

\section{DISCUSSION}

\section{Methodological considerations}

To our knowledge, the present study is the first to compare profiles of freshwater virioplankton communities using RAPD-PCR. Previous concerns regarding RAPD-PCR focused on the assumptions that only viral templates are being amplified and that the banding patterns produced from this amplification are reproducible. In the present study, as with previous studies using RAPD-PCR on viral assemblages (Winget \& Wommack 2008, Helton \& Wommack 2009, Winter \& Weinbauer 2010), the purity of VC and lack of microbial contamination was confirmed by epifluorescence microscopy (see Fig. S7 in the supplement). Twenty fields were examined for each VC and confirmed to be free of bacterial cells before proceeding with further analysis. Furthermore, treatment of VC with DNase did not result in changes in banding patterns (Fig. S5 in the supplement). Both of these observations support the conclusion that RAPD banding patterns originated from viral templates. Replicate RAPD-PCR reactions yielded banding patterns of $\geq 80 \%$ similarity (Fig. 2; Fig. S5 in the supplement), consistent with the reproducibility cited by other studies (Winget \& Wommack 2008, Helton \& Wommack 2009).

As an amplified fragment polymorphism technique, RAPD-PCR suffers from the same issues as 16S rRNA gene-based profiling methods, such as tRFLP and denaturing gradient gel electrophoresis (DGGE). The main concerns are that some templates may be preferentially amplified over others (Polz \& Cavanaugh 1998) and that some genomes may contain multiple copies of the template sequence 
(Crosby \& Criddle 2003). However, these biases are largely accepted in the use of 16S rRNA gene-based data to examine microbial communities, and it is therefore difficult to reject RAPD-PCR on these grounds alone. A recent paper investigated the ecological interpretation of RAPD-PCR results in the study of aquatic viral communities and provides a reasonable assessment of potential biases introduced by this technique (Winter \& Weinbauer 2010). Unlike the 16S rRNA gene, no universal sequence target exists among the viruses. Thus, it is important to note that the primer favored in most RAPD-PCR studies, CRA-22, only captures the richness and dynamics of some unknown subset of the viral community. That said, RAPD-PCR remains a powerful tool for documenting change in viral community composition and for identifying relationships between viral community change and other biological and environmental factors (Winter \& Weinbauer 2010). In the present study, we found that RAPD-PCR is highly sensitive to changes in viral community composition and holds several advantages over the more commonly used viral profiling technique, PFGE.

We examined more closely the utility of RAPD-PCR for profiling freshwater viral communities largely because preliminary field studies using PFGE yielded unsatisfactory results. Pulsed-field gels of freshwater viral assemblages from the present study (see Fig. S3 in the supplement) and others (Auguet et al. 2006, Filippini \& Middelboe 2007, Tijdens et al. 2008) tend to produce relatively few, often highly diffuse bands compared to those originating from marine concentrates, reducing the discriminatory power of PFGE in analyzing freshwater viral communities. In addition, large numbers of virus particles must be loaded into gels to resolve bands. Thus, most PFGE-based analyses of aquatic viral community composition have used TFF to concentrate viruses from water samples, using volumes from 12 to 801 (Auguet et al. 2006, Filippini \& Middelboe 2007, Parada et al. 2007, Winget \& Wommack 2008). While previous reports have indicated that the sensitivity of PFGE can be as low as $10^{6}$ viruses per band (Wommack et al. 1999, Filippini \& Middelboe 2007), viral concentrates from Lake Matoaka required a minimum of $10^{9}$ viruses per lane to resolve any bands (Fig. S4 in the supplement). Even a 10 -fold reduction in virus concentration dramatically reduced the number of detectable bands by PFGE.

Current investigations using RAPD-PCR to analyze changes in aquatic viral community composition have relied upon TFF to concentrate viruses from large sample volumes prior to amplification (Winget \& Wommack 2008, Winter \& Weinbauer 2010). How- ever, given that successful RAPD-PCR of aquatic viral templates requires $\sim 10^{5}$ particles per reaction (Srinivasiah et al. 2008) and that overloading of DNA templates frequently reduces the complexity of RAPD banding patterns (see Fig. S1 in the supplement), TFF concentration of viruses from large sample volumes may not be necessary. Our results indicate that for water samples containing an ambient viral abundance of at least $10^{6}$ viruses $\mathrm{ml}^{-1}, \mathrm{UCF}$ of a $50 \mathrm{ml}$ sample produces viral concentrates sufficient to generate RAPD banding patterns from $1 \mu \mathrm{l}$ of VC. Furthermore, the use of smaller sample volumes to generate VC did not lead to any losses in the ability to detect changes in viral richness or viral community composition by RAPD-PCR (Figs. 2 \& 3). In fact, viral richness (number of RAPD band types) was slightly higher when UCF concentrates were used compared to larger volume TFF concentrates (Table 3). This may be due to a slightly higher efficiency of UCF to concentrate viruses as compared to TFF, which has been observed elsewhere (Takashima et al. 2007).

It is important to note that PFGE remains a viable option for assessing aquatic viral community composition, particularly for marine samples. Furthermore, TFF is still advantageous if field work necessitates the processing of large-volume water samples shipboard. However, for freshwater studies (particularly where lab access is available), the application of UCF viral concentrates in tandem with RAPD-PCR can increase sample throughput and allow more information to be obtained regarding viral dynamics using smaller sample volumes. For example, in 1 microcosm study performed by Auguet et al. (2006), fingerprints of viral communities in $4 \mathrm{l}$ batch experiments could not be obtained due to the volume constraints of PFGE (requiring at least $10 \mathrm{l}$ of water to generate bands by PFGE). Due to this constraint, potential changes in viral community composition could not be compared with contemporaneous bacterial community data. Preparation of viral concentrates by ultracentrifugation of $50 \mathrm{ml}$ samples and subsequent analysis of changes in viral community composition by RAPD-PCR could have enabled such comparisons.

Finally, recent studies have shown that particleassociated microbial communities may be quite different from planktonic communities (Mari et al. 2007, Riemann \& Grossart 2008, Luef et al. 2009). However, it is important to note that due to the filtration steps involved in obtaining bacterial assemblages and viral concentrates, the present study focuses exclusively on the planktonic fraction of the lake's microbial community. While most previous aquatic studies have included a $0.22 \mu \mathrm{m}$ filtration step to remove 
bacterial cells prior to generating viral concentrates, we cannot ignore the possibility that this filtration step has excluded certain large viruses from the viral community analysis in the present study. While several large algal viruses, such as Chlorella viruses (e.g. PBCV-1, $190 \mathrm{~nm}$ diameter) (Van Etten et al. 1991) and diatom viruses (e.g. EhV, $180 \mathrm{~nm}$ diameter) (Jacquet et al. 2002), should be able to pass through a $0.22 \mu \mathrm{m}$ filter, larger viruses, such as Cafeteria roenbergensis virus $\left(\mathrm{CroV}_{1} 300 \mathrm{~nm}\right.$ diameter) (Fischer et al. 2010), would likely be retained on a $0.22 \mu \mathrm{m}$ filter. Although CroV infects a marine alga and no freshwater algal viruses of this size have been yet reported, it is possible that some unknown fraction of large algal viruses were eliminated from our analysis, thus skewing the results toward phages. However, we temper this possibility with the fact that electron microscopic observation of aquatic virioplankton suggests that the majority are tailed phages (Wommack \& Colwell 2000, Weinbauer 2004).

\section{Ecological considerations}

\section{Abundance}

Bacterial dynamics were similar to those observed in other freshwater systems, with minimal abundances in winter and maximal abundances observed in spring (2009) or early autumn (2010; Fig. 1). The average bacterial abundance in Lake Matoaka is somewhat low compared to shallow eutrophic lakes in Europe (Lymer et al. 2008b, Tijdens et al. 2008, Personnic et al. 2009), although within the range of reported values for several shallow eutrophic lakes in China (Cheng et al. 2010).

Viral abundances in Lake Matoaka were within the range reported for other freshwater ecosystems (Wommack \& Colwell 2000), albeit somewhat low compared to other eutrophic lakes. Temperature was strongly correlated with both bacterial and viral abundance in Lake Matoaka, consistent with many other studies (Jiang \& Paul 1994, Allgaier \& Grossart 2006, Boucher et al. 2006, Tijdens et al. 2008). However, viral abundance in Lake Matoaka was not correlated to dissolved nutrient levels, as has been observed in other lakes (Peduzzi \& Schiemer 2004, Lymer et al. 2008a, Personnic et al. 2009).

While several studies have found viral abundance in freshwater lakes to be strongly correlated to chl $a$ levels (Madan et al. 2005, Liu et al. 2006, Tijdens et al. 2008), other studies have found viral abundance in certain lakes (Personnic et al. 2009, Cheng et al.
2010) and many marine systems (Maranger \& Bird 1995) to be significantly correlated with bacterial abundance. These differences could indicate differences in the dominance of certain types of virioplankton (bacteriophages vs. cyanophages or algal viruses, for example) among different ecosystems. Alternatively, the differences in correlation could be due to sampling interval or the ways in which samples are compared. For example, a study comparing 7 sampling sites across 2 lakes found that viral abundance was significantly correlated to bacterial abundance based on temporal variation within each sampling site. However, when correlations were based on spatial variation across different sampling sites, viral abundance was not related to bacterial abundance but instead strongly related to chl $a_{\text {, total } \mathrm{N}}$ and total P (Cheng et al. 2010). In the present study, the strong correlations between viral and bacterial abundance in Lake Matoaka suggest that viral and bacterial dynamics are tightly linked and support the hypothesis that the majority of the lake virioplankton are bacteriophages.

\section{Community composition}

Marked seasonal shifts in bacterial community composition appear to be a common feature of temperate freshwater lakes (Hofle et al. 1999, Van der Gucht et al. 2001, Lymer et al. 2008b). In spite of numerous studies that have explored freshwater microbial community composition, few common factors have been identified that best explain community composition change in all freshwater ecosystems (Hiorns et al. 1997, Lindström 2000, Boucher et al. 2006, Newton et al. 2011).

Previous studies have demonstrated that annual variations in microbial community composition are not generally repeated over annual cycles in eutrophic lakes (Lindström 2000, Boucher et al. 2006). Repeating seasonal trends have, however, been identified in humic and oligotrophic lakes (Yannarell et al. 2003, Lymer et al. 2008b). In eutrophic lakes, microbial community composition appears to be highly variable over time (Lindström 2000) and may even change rapidly on relatively short timescales (Lymer et al. 2008b). Such observations are consistent with the dynamic bacterial community and lack of repeating annual cycles in bacterial community composition in the present study.

Using multivariate statistical approaches, different studies have identified different factors as potential drivers of bacterial community composition changes 
in freshwater lakes. In 1 study that examined 3 different lakes, temperature was shown to account for 43 to $60 \%$ of community composition change over time using canonical correspondence analysis (Lymer at al. 2008b). A separate study comparing 15 temperate lakes ranging from oligomesotrophic to hypereutrophic found that temperature, $\mathrm{pH}$ and water residence time were the primary factors that determined bacterial community composition, with the 3 variables in aggregate accounting for $64 \%$ of the variance. However, when considered separately, temperature alone was a relatively weak explanatory factor, with an eigenvalue of -0.3887 (Lindström et al. 2005). In the present study, a similarly weak relationship was identified between temperature and temporal change in bacterial community composition in Lake Matoaka ( $\mathrm{r}=0.5670$, Hinf I profile; $\mathrm{r}=0.5660$, MspI profile) (see Table S2 in the supplement). However, as mentioned above, temperature was strongly correlated with both viral and bacterial abundance. This combination of a stronger relationship between microbial abundance and temperature but a weak or no relationship between temperature and community composition has been reported in several other freshwater studies (Allgaier \& Grossart 2006, Boucher et al. 2006, Tijdens et al. 2008). We noted that bacterial richness was generally lowest in the late summer/early autumn and that richness was not significantly correlated to bacterial abundance. We hypothesize that the decrease in bacterial richness was due to dominance by fewer bacterial species in the summer, whereas the increased richness in winter was due to an increase in evenness among bacterial taxa in the lake. This hypothesis is supported by a separate study in which nutrient enrichment of an Antarctic lake induced the growth of specific bacterial taxa, resulting in a net increase in total bacterioplankton abundance but a decrease in overall richness (Pearce et al. 2005).

$\mathrm{pH}$ has also been identified as a significant driver of community composition change. In addition to the study by Lindström et al. (2005), a separate study found significant clustering of bacterial communities by $\mathrm{pH}$ across 5 different lakes, with a Pearson's correlation between $\mathrm{pH}$ and bacterial richness of 0.785 (Allgaier \& Grossart 2006). In the present study, no meaningful correlation was observed between community composition and $\mathrm{pH}(\mathrm{r}=0.316$; $\mathrm{p}=0.251)$. However, it is important to note that the study by Allgaier et al. (2006) examined 5 lakes with different properties (i.e. different trophic statuses and humic contents), and while $\mathrm{pH}$ was the only explanatory factor common to all 5, different environmental fac- tors were found to drive community change in each of the 5 lakes (Allgaier \& Grossart 2006). As the present study focused on 1 lake and the $\mathrm{pH}$ within the lake fluctuated only moderately (Table 1), this may explain why $\mathrm{pH}$ did not have any explanatory power in accounting for bacterial community composition change.

Indeed, the general lack of strong correlations between environmental and biological data may be explained by the fact that most of the measured environmental variables were fairly stable over the sampling period (Table 1). The weak correlation with temperature has been observed in other freshwater studies and may be explained by thermal selection for species with different growth kinetics (Hall et al. 2008). However, since temperature can influence patterns in other organisms such as aquatic macrophytes (Bornette \& Puijalon 2011), algae and cyanobacteria (Elliott 2012), all of which contribute to the quantity and quality of dissolved organic matter, the relationship between temperature and bacterial and viral community composition may also be indirect.

Viruses are obligate genetic parasites and thus engage in predator-prey type oscillations with their hosts in terms of abundance and community composition (Fuhrman 1999, Thingstad 2000, Weinbauer 2004). While viral community composition has been investigated in several marine settings (Wommack et al. 1999, Steward et al. 2000, Fuhrman et al. 2002, Riemann \& Middelboe 2002, Jiang et al. 2003, Hewson et al. 2006, Parada et al. 2008), relatively few studies have quantitatively analyzed virioplankton community composition in freshwater lakes. Of these existing freshwater studies, few explanatory factors have been identified that account for observed changes in virus community composition. An annual study of virioplankton using PFGE in 3 Scandinavian lakes identified dissolved nutrients (dissolved organic carbon [DOC], soluble reactive phosphorus and total nitrogen) as the best factors explaining shifts viral community composition, but with weak eigenvalues of $<0.3$ (Lymer et al. 2008b). This differs from Lake Matoaka, where temperature was the best explanatory factor accounting for changes in viral community composition. However, it is important to point out that DOC was not measured in the present study; thus, potential relationships between DOC and biological parameters, such as abundance and community compositions, could not be determined for Lake Matoaka. Similar to results reported by Lymer et al. (2008b), the relationship between environmental factors (temperature) and viral community composition in Lake Matoaka was weak ( $\mathrm{r}=0.5602$; 
Table S2 in the supplement). In their study, the application of Mantel tests by Lymer et al. (2008b) revealed that bacterial community composition and viral community composition in the Scandinavian lakes were also linked, though the correlation coefficient was fairly weak $(\mathrm{r}=0.48)$.

In a separate study of virioplankton composition in a Dutch lake, PFGE indicated that viral assemblages were largely stable over the observation period, with samples differing primarily in band intensity (Tijdens et al. 2008). This is reminiscent of our preliminary analysis of Lake Matoaka using PFGE, in which very little change in banding patterns was observed over 5 mo (see Fig. S3 in the supplement), and underscores the high likelihood that PFGE may not be sensitive enough to capture important fluctuations in freshwater viral community composition. While significant correlations were found between viral abundance and bacterial community composition as well as bacterial abundance and viral community composition, no significant relationship was identified between bacterial and viral community composition. The authors speculated that 'more specific techniques with a higher resolution might be necessary to reveal virus-host interactions in natural assemblages' (Tijdens et al. 2008).

\section{Intersection of methods development} and ecological data

A recent study of viral community dynamics in the Mediterranean Sea serves to illustrate the utility of RAPD-PCR as just such a high resolution technique (Winter \& Weinbauer 2010). Using RAPD-PCR, researchers identified a strong relationship $(r=0.82)$ between bacterial richness and viral richness in the epipelagic zone. Weaker relationships were observed between viral and bacterial richness in the mesopelagic $(r=0.6)$ and bathypelagic zones $(r=$ -0.64). Most interestingly, Mantel tests revealed that changes in bacterial community composition were strongly linked to changes in the viral community composition, particularly in the bathypelagic zone $(r=0.61)$, indicating a highly responsive and dynamic viral community. That study was the first to employ RAPD-PCR to document temporal and spatial change in viral community composition, and to compare viral RAPD data with contemporaneous bacterial profiles. The results clearly demonstrated the utility of RAPD as a sensitive and high-resolution technique for revealing virus-host interactions in natural assemblages.
Results from the present study support the idea that RAPD-PCR provides higher resolution data than PFGE for analyzing freshwater virioplankton dynamics. The use of RAPD-PCR to analyze viral community composition of Lake Matoaka revealed an extremely strong link between viral and bacterial communities $(\mathrm{r}=0.9975, \mathrm{p}=0.0001$, Hinf $\mathrm{I}$ profile; $\mathrm{r}=$ 0.9976, $p=0.0001$, MspI profile). The strength of this correlation is much higher than any reported so far and may be a result of the increased sensitivity of RAPD-PCR to changes in the viral community relative to PFGE. Since it has been established that the CRA-22 primer captures some unknown subset of total viral richness, it is possible that the virioplankton in Lake Matoaka have a high frequency of primer binding sites. This would increase the sensitivity of our methods for detecting changes in Lake Matoaka virioplankton community structure. This seems unlikely, however, since the RAPD band richness in our samples were comparable to those found in the Mediterranean study (Winter \& Weinbauer 2010). Regardless, the observed strong correlation between viral and bacterial community composition, in conjunction with the strong relationship between viral and bacterial abundance, indicates that viral and bacterial dynamics in Lake Matoaka are very tightly linked. However, much work remains to determine the directionality of this relationship as well as the ultimate drivers of both viral and bacterial community succession.

Based on community assembly patterns observed in other freshwater ecosystems, it is highly likely that freshwater bacterial communities are impacted by the introduction or invasion of terrestrial bacteria (Lindström et al. 2005). The same may be true of viruses; however, no known studies have directly investigated the impacts of terrestrial viruses on aquatic bacterial dynamics. In addition to microbial inputs, high levels of terrestrial DOC inputs are a prominent feature of many freshwater lakes (Jansson et al. 1999, Cole et al. 2007) and can be a significant factor impacting bacterial community composition (Judd et al. 2006, Jones et al. 2009). Due to lack of instrumentation and support for DOC analysis, this was not included in the present study. However, DOC may well be an important factor explaining the observed changes in bacterial and viral community composition. Thus, future work will test for relationships between DOC quantity and quality and changes in virio- and bacterioplankton dynamics in Lake Matoaka. In addition, we will also explore the contribution of allochthonous terrestrial viruses and bacteria in driving shifts in community composition. 
Acknowledgements. We thank L. Epp for running capillary electrophoresis and assistance with tRFLP analysis. We thank E. Orlova and D. Kiernan for assistance with field sampling and recording environmental data. Thanks to R. Chambers and the staff of the Keck Environmental Field Laboratory for water chemical analysis. Thanks also to $\mathrm{M}$. Saxton and S. Williamson for reading the manuscript. This work was supported by a grant to K.E.W. from the Jeffress Memorial Trust (J-988).

\section{LITERATURE CITED}

Allgaier M, Grossart HP (2006) Seasonal dynamics and phylogenetic diversity of free-living and paricle-associated bacterial communities in four lakes in northeastern Germany. Aquat Microb Ecol 45:115-128

> Auguet JC, Montanie H, Lebaron P (2006) Structure of virioplankton in the Charente Estuary (France): transmission electron microscopy versus pulsed field gel electrophoresis. Microb Ecol 51:197-208

Berdjeb L, Pollet T, Domaizon I, Jacquet S (2011) Effect of grazers and viruses on bacterial community structure and production in two contrasting trophic lakes. BMC Microbiol 11:88

> Bornette G, Puijalon S (2011) Response of aquatic plants to abiotic factors: a review. Aquat Sci 73:1-14

> Boucher D, Jardillier L, Debroas D (2006) Succession of bacterial community composition over two consecutive years in two aquatic systems: a natural lake and a lake-reservoir. FEMS Microbiol Ecol 55:79-97

> Cheng K, Pei D, Zhao YJ, Deng FX, Liu W, Zhao J (2010) Temporal and spatial distribution of virioplankton in large shallow freshwater lakes. Chin J Oceanology Limnol 28:868-873

> Clarke KR, Ainsworth M (1993) A method of linking multivariate community structure to environmental variables. Mar Ecol Prog Ser 92:205-219

> Clasen JL, Brigden SM, Payet JP, Suttle CA (2008) Evidence that viral abundance across oceans and lakes is driven by different biological factors. Freshw Biol 53:1090-1100

> Cole JJ, Prairie YT, Caraco NF, McDowell WH and others (2007) Plumbing the global carbon cycle: integrating inland waters into the terrestrial carbon budget. Ecosystems 10:172-185

Crosby LD, Criddle CS (2003) Understanding bias in microbial community analysis techniques due to rrn operon copy number heterogeneity. Biotechniques 34:790-794

> Crump BC, Kling GW, Bahr M, Hobbie JE (2003) Bacterioplankton community shifts in an arctic lake correlate with seasonal changes in organic matter source. Appl Environ Microbiol 69:2253-2268

Elliott JA (2012) Is the future blue-green? A review of the current model predictions of how climate change could affect pelagic freshwater cyanobacteria. Water Res 46 : 1364-1371

> Filippini M, Middelboe M (2007) Viral abundance and genome size distribution in the sediment and water column of marine and freshwater ecosystems. FEMS Microbiol Ecol 60:397-410

> Fischer MG, Allen MJ, Wilson WH, Suttle CA (2010) Giant virus with a remarkable complement of genes infects marine zooplankton. Proc Natl Acad Sci USA 107: 19508-19513

Fuhrman JA (1999) Marine viruses and their biogeochemical and ecological effects. Nature 399:541-548
Fuhrman JA, Griffith JF, Schwalbach MS (2002) Prokaryotic and viral diversity patterns in marine plankton. Ecol Res 17:183-194

Hall EK, Neuhauser C, Cotner JB (2008) Toward a mechanistic understanding of how natural bacterial communities respond to changes in temperature in aquatic ecosystems. ISME J 2:471-481

Hammer $\varnothing$, Harper DAT, Ryan PD (2001) PAST: paleontological statistics software package for education and data analysis. Palaeontol Electronica 4:9

Helton RR, Wommack KE (2009) Seasonal dynamics and metagenomic characterization of estuarine viriobenthos assemblages by randomly amplified polymorphic DNA PCR. Appl Environ Microbiol 75:2259-2265

> Hewson I, Wingett DM, Williamson KE, Fuhrman JA, Wommack KE (2006) Viral and bacterial assemblage covariance in oligotrophic waters of the West Florida Shelf (Gulf of Mexico). J Mar Biol Assoc UK 86:591-603

> Hewson I, Brown JM, Gitlin SA, Doud DF (2011) Nucleopolyhedrovirus detection and distribution in terrestrial, freshwater, and marine habitats of Appledore Island, Gulf of Maine. Microb Ecol 62:48-57

> Hiorns WD, Methe BA, Nierzwicki-Bauer SA, Zehr JP (1997) Bacterial diversity in Adirondack Mountain lakes as revealed by $16 \mathrm{~S}$ rRNA gene sequences. Appl Environ Microbiol 63:2957-2960

> Höfle MG, Haas H, Dominik K (1999) Seasonal dynamics of bacterioplankton community structure in a eutrophic lake as determined by 5S rRNA analysis. Appl Environ Microbiol 65:3164-3174

Jacquet S, Heldal M, Iglesias-Rodriguez D, Larsen A, Wilson W, Bratbak G (2002) Flow cytometric analysis of an Emiliana huxleyi bloom terminated by viral infection. Aquat Microb Ecol 27:111-124

> Jacquet S, Domaizon I, Personnic S, Sime-Ngando T (2007) Do small grazers influence virus-induced mortality of bacteria in Lake Bourget (France)? Fund Appl Limnol 170:125-132

Jansson M, Bergstrom AK, Blomqvist P, Isaksson A, Jonsson A (1999) Impact of allochthonous organic carbon on microbial food web carbon dynamics and structure in Lake Ortrasket. Arch Hydrobiol 144:409-428

Jiang SC, Paul JH (1994) Seasonal and diel abundance of viruses and occurrence of lysogeny/bacteriocinogeny in the marine environment. Mar Ecol Prog Ser 104:163-172

> Jiang S, Fu W, Chu W, Fuhrman JA (2003) The vertical distribution and diversity of marine bacteriophage at a station off Southern California. Microb Ecol 45:399-410

> Jones SE, Newton RJ, McMahon KD (2009) Evidence for structuring of bacterial community composition by organic carbon source in temperate lakes. Environ Microbiol 11:2463-2472

Judd KE, Crump BC, Kling GW (2006) Variation in dissolved organic matter controls bacterial production and community composition. Ecology 87:2068-2079

> Kent AD, Jones SE, Yannarell AC, Graham JM, Lauster GH, Kratz TK, Triplett EW (2004) Annual patterns in bacterioplankton community variability in a humic lake. Microb Ecol 48:550-560

Lane DJ (1991) 16S/23S rRNA sequencing. In: Stackebrandt E, Goodfellow M (eds) Nucleic acid techniques in bacterial systematics. John Wiley \& Sons, New York, NY, p 115-175

> Lindström ES (2000) Bacterioplankton community composition in five lakes differing in trophic status and humic content. Microb Ecol 40:104-113 
Lindström ES, Kamst-Van Agterveld MP, Zwart G (2005) Distribution of typical freshwater bacterial groups is associated with $\mathrm{pH}$, temperature, and lake water retention time. Appl Environ Microbiol 71:8201-8206

Liu WT, Marsh TL, Cheng H, Forney LJ (1997) Characterization of microbial diversity by determining terminal restriction fragment length polymorphisms of genes encoding 16S rRNA. Appl Environ Microbiol 63:4516

Liu YM, Zhang QY, Yuan XP, Li ZQ, Gui JF (2006) Seasonal variation of virioplankton in a eutrophic shallow lake. Hydrobiologia 560:323-334

Lorenzen CJ (1967) Determination of chlorophyll and phaeopigments: spectrophotometric equations. Limnol Oceanogr 12:343-346

Luef B, Neu TR, Peduzzi P (2009) Imaging and quantifying virus fluorescence signals on aquatic aggregates: a new method and its implication for aquatic microbial ecology. FEMS Microbiol Ecol 68:372-380

Lymer D, Lindström ES, Vrede K (2008a) Variable importance of viral-induced bacterial mortality along gradients of trophic status and humic content in lakes. Freshw Biol 53:1101-1113

> Lymer D, Logue JB, Brussaard CPD, Baudoux AC, Vrede K, Lindström ES (2008b) Temporal variation in freshwater viral and bacterial community composition. Freshw Biol 53:1163-1175

> Madan NJ, Marshall WA, Laybourn-Parry J (2005) Virus and microbial loop dynamics over an annual cycle in three contrasting Antarctic lakes. Freshw Biol 50: 1291-1300

Maranger R, Bird DF (1995) Viral abundance in aquatic systems: a comparison between marine and fresh waters. Mar Ecol Prog Ser 121:217-226

Mari X, Kerros ME, Weinbauer MG (2007) Virus attachment to transparent exopolymeric particles along trophic gradients in the southwestern lagoon of New Caledonia. Appl Environ Microbiol 73:5245-5252

Melo AS (2009) Explaining dissimilarities in macroinvertebrate assemblages among stream sites using environmental variables. Zoologia 26:79-84

> Miki T, Nakazawa T, Yokokawa T, Nagata T (2008) Functional consequences of viral impacts on bacterial communities: a food-web model analysis. Freshw Biol 53: 1142-1153

Newton RJ, Jones SE, Eiler A, McMahon KD, Bertilsson S (2011) A guide to the natural history of freshwater lake bacteria. Microbiol Mol Biol Rev 75:14-49

Noble RT, Fuhrman JA (1998) Use of SYBR Green I for rapid epifluorescence counts of marine viruses and bacteria. Aquat Microb Ecol 14:113-118

> Parada V, Sintes E, van Aken HM, Weinbauer MG, Herndl GJ (2007) Viral abundance, decay, and diversity in the meso- and bathypelagic waters of the North Atlantic. Appl Environ Microbiol 73:4429-4438

Parada V, Baudoux AC, Sintes E, Weinbauer MG, Herndl GJ (2008) Dynamics and diversity of newly produced virioplankton in the North Sea. ISME J 2:924-936

Parsons TR, Maita Y, Lalli CM (1984) A manual of chemical and biological methods for seawater analysis. Pergamon Press, Oxford

> Pearce DA, Van der Gast CJ, Woodward K, Newsham KK (2005) Significant changes in the bacterioplankton community structure of a maritime Antarctic freshwater lake following nutrient enrichment. Microbiology 151: 3237-3248
Peduzzi P, Schiemer F (2004) Bacteria and viruses in the water column of tropical freshwater reservoirs. Environ Microbiol 6:707-715

> Pensa MA, Chambers RM (2004) Trophic transition in a lake on the Virginia coastal plain. J Environ Qual 33:576-580

Pernthaler J, Glockner FO, Unterholzner S, Alfreider A, Psenner R, Amann R (1998) Seasonal community and population dynamics of pelagic bacteria and archaea in a high mountain lake. Appl Environ Microbiol 64: 4299-4306

Personnic S, Domaizon I, Dorigo U, Berdjeb L, Jacquet S (2009) Seasonal and spatial variability of virio-, bacterio-, and picophytoplanktonic abundances in three perialpine lakes. Hydrobiologia 627:99-116

Polz MF, Cavanaugh CM (1998) Bias in template-to-product ratios in multitemplate PCR. Appl Environ Microbiol 64: 3724-3730

R Development Core Team (2012) R: a language and environment for statistical computing. R Foundation for statistical Computing, Vienna, www.R-project.org

Riemann L, Grossart HP (2008) Elevated lytic phage production as a consequence of particle colonization by a marine Flavobacterium (Cellulophaga sp.). Microb Ecol 56: 505-512

Riemann L, Middelboe M (2002) Stability of bacterial and viral community compositions in Danish coastal waters as depicted by DNA fingerprinting techniques. Aquat Microb Ecol 27:219-232

Rusch DB, Halpern AL, Sutton G, Heidelberg KB and others (2007) The Sorcerer II Global Ocean Sampling expedition: Northwest Atlantic through Eastern Tropical Pacific. PLoS Biol 5:e77

> Short CM, Rusanova O, Short SM (2011) Quantification of virus genes provides evidence for seed-bank populations of phycodnaviruses in Lake Ontario, Canada. ISME J 5: $810-821$

> Sime-Ngando T, Ram ASP (2005) Grazer effects on prokaryotes and viruses in a freshwater microcosm experiment. Aquat Microb Ecol 41:115-124

> Simek K, Weinbauer MG, Hornak K, Jezbera J, Nedoma J, Dolan JR (2007) Grazer and virus-induced mortality of bacterioplankton accelerates development of Flectobacillus populations in a freshwater community. Environ Microbiol 9:789-800

Srinivasiah S, Bhavsar J, Thapar K, Liles M, Schoenfeld T, Wommack KE (2008) Phages across the biosphere: contrasts of viruses in soil and aquatic environments. Res Microbiol 159:349-357

Steward GF (2001) Fingerprinting viral assemblages by pulsed field gel electrophoresis (PFGE). In: Paul JH (ed) Methods in Microbiology, Vol 30. Academic Press, San Diego, CA, p 85-103

> Steward GF, Montiel JL, Azam F (2000) Genome size distributions indicate variability and similarities among marine viral assemblages from diverse environments. Limnol Oceanogr 45:1697-1706

> Suttle CA, Chan AM, Cottrell MT (1991) Use of ultrafiltration to isolate viruses from seawater which are pathogens of marine phytoplankton. Appl Environ Microbiol 57:721-726

- Takashima Y, Yoshida T, Yoshida M, Shirai Y and others (2007) Development and application of quantitative detection of cyanophages phylogenetically related to cyanophage Ma-LMM01 infecting Microcystis aeruginosa in fresh water. Microbes Environ 22:207-213 
Thingstad TF (2000) Elements of a theory for the mechanisms controlling abundance, diversity, and biogeochemical role of lytic bacterial viruses in aquatic systems. Limnol Oceanogr 45:1320-1328

Tijdens M, Hoogveld HL, Kamst-van Agterveld MP, Simis SGH, Baudoux AC, Laanbroek HJ, Gons HJ (2008) Population dynamics and diversity of viruses, bacteria and phytoplankton in a shallow eutrophic lake. Microb Ecol 56:29-42

> Van der Gucht K, Sabbe K, De Meester L, Vloemans N, Zwart G, Gillis M, Vyverman W (2001) Contrasting bacterioplankton community composition and seasonal dynamics in two neighbouring hypertrophic freshwater lakes. Environ Microbiol 3:680-690

> Van Etten JL, Lane LC, Meints RH (1991) Viruses and viruslike particles of eukaryotic algae. Microbiol Rev 55: 586-620

Weinbauer MG (2004) Ecology of prokaryotic viruses. FEMS Microbiol Rev 28:127-181

> Weinbauer MG, Hofle MG (1998) Significance of viral lysis and flagellate grazing as factors controlling bacterioplankton production in a eutrophic lake. Appl Environ Microbiol 64:431-438

Wen K, Ortmann AC, Suttle CA (2004) Accurate estimation of viral abundance by epifluorescence microscopy. Appl Environ Microbiol 70:3862-3867

Editorial responsibility: Gunnar Bratbak, Bergen, Norway
Winget DM, Wommack KE (2008) Randomly amplified polymorphic DNA PCR as a tool for assessment of marine viral richness. Appl Environ Microbiol 74: 2612-2618

Winter C, Weinbauer MG (2010) Randomly amplified polymorphic DNA reveals tight links between viruses and microbes in the bathypelagic zone of the northwestern Mediterranean Sea. Appl Environ Microbiol 76: 6724-6732

Wommack KE, Colwell RR (2000) Virioplankton: viruses in aquatic ecosystems. Microbiol Mol Biol Rev 64:69-114

> Wommack KE, Ravel J, Hill RT, Colwell RR (1999) Population dynamics of Chesapeake Bay virioplankton: total community analysis using pulsed field gel electrophoresis. Appl Environ Microbiol 65:231-240

Wu QLL, Hahn MW (2006) High predictability of the seasonal dynamics of a species-like Polynucleobacter population in a freshwater lake. Environ Microbiol 8: 1660-1666

Yannarell AC, Kent AD, Lauster GH, Kratz TK, Triplett EW (2003) Temporal patterns in bacterial communities in three temperate lakes of different trophic status. Microb Ecol 46:391-405

Zwisler W, Selje N, Simon M (2003) Seasonal patterns of the bacterioplankton community composition in a large mesotrophic lake. Aquat Microb Ecol 31:211-225

Submitted: April 3, 2012; Accepted: July 6, 2012 Proofs received from author(s): August 29, 2012 